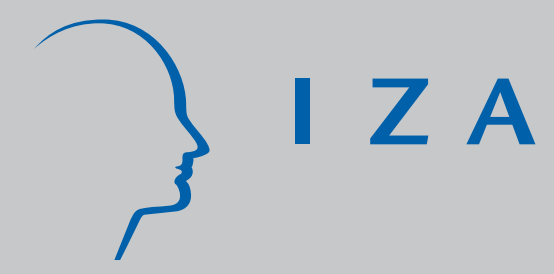

IZA DP No. 1903

On Human Capital Formation with Exit Options:

Comment and New Results

Panu Poutvaara

December 2005 


\title{
On Human Capital Formation with Exit Options: Comment and New Results
}

\author{
Panu Poutvaara \\ University of Helsinki \\ and IZA Bonn
}

\section{Discussion Paper No. 1903 \\ December 2005}

\author{
IZA \\ P.O. Box 7240 \\ 53072 Bonn \\ Germany \\ Phone: +49-228-3894-0 \\ Fax: +49-228-3894-180 \\ Email: iza@iza.org
}

\begin{abstract}
Any opinions expressed here are those of the author(s) and not those of the institute. Research disseminated by IZA may include views on policy, but the institute itself takes no institutional policy positions.
\end{abstract}

The Institute for the Study of Labor (IZA) in Bonn is a local and virtual international research center and a place of communication between science, politics and business. IZA is an independent nonprofit company supported by Deutsche Post World Net. The center is associated with the University of Bonn and offers a stimulating research environment through its research networks, research support, and visitors and doctoral programs. IZA engages in (i) original and internationally competitive research in all fields of labor economics, (ii) development of policy concepts, and (iii) dissemination of research results and concepts to the interested public.

IZA Discussion Papers often represent preliminary work and are circulated to encourage discussion. Citation of such a paper should account for its provisional character. A revised version may be available directly from the author. 
IZA Discussion Paper No. 1903

December 2005

\section{ABSTRACT \\ On Human Capital Formation with Exit Options: Comment and New Results}

Katz and Rapoport (2005) conclude that with linear production technology and the possibility of unilateral migration, region-specific shocks may increase the average level of education. Previously, Poutvaara (2000) derived a corresponding result with Cobb-Douglas technology and migration which may go in both directions. This paper shows that the exit option may reduce human capital formation with a quadratic production technology.

JEL Classification: F22, J24, I21

Keywords: human capital formation, migration, economic volatility

Corresponding author:

Panu Poutvaara

Department of Economics

P.O. Box 17 (Arkadiankatu 7)

FIN-00014 University of Helsinki

Finland

Email: panu.poutvaara@helsinki.fi 


\section{Introduction}

In their recent contribution, Katz and Rapoport (2005) explore the relationship between economic volatility and human capital formation in a twocountry framework. In one country, the rate of return to human capital is certain. In the other country, it is uncertain but of the same expected value. Katz and Rapoport find that increased variability in the unstable country, which they call undeveloped, increases investment in education there. The reason for this is that the exit option provides an insurance for those who have sufficiently low migration costs.

Previously, also Poutvaara (2000) studied the effect of region-specific shocks on human capital formation when the regions have the same expected rate of return to human capital. Poutvaara (2000) assumes that two regions face symmetric and opposite shocks, and both have ex ante an identical chance of a positive and a negative shock. Also Poutvaara (2000) finds that the individual investment in human capital is increasing in the magnitude of shocks when migration is allowed. Unlike Katz and Rapoport (2005), Poutvaara (2000) assumes that migration can go in either direction. Another difference is in production technology: Katz and Rapoport (2005) assume that production is linear in human capital, while Poutvaara (2000) assumes a Cobb-Douglas production technology which combines human capital and a region-specific fixed factor. Katz and Rapoport assume ex ante heterogeneous and risk-neutral individuals, while Poutvaara (2000) assumes that those who became educated are ex ante identical and that they may be risk-averse. The third difference is that Poutvaara (2000) allows everyone to emigrate, while Katz and Rapoport (2005) assume that the costs of adjustment and preferences for living in the home country restrict emigration.

This comment extends the finding by Poutvaara (2000) and Katz and Rapoport (2005) by showing that the results that they derive with linear and Cobb-Douglas production technology may be reversed with other production technologies. The comment follows Katz and Rapoport (2005) by focusing on risk-neutral individuals in the absence of taxation. As Poutvaara (2000), the comment derives the results when individuals are ex ante identical. The results could be easily generalized to the case of ex ante different productivities, in line with the appendix A in Köthenbürger and Poutvaara (forthcoming). 


\section{The Model}

\subsection{A Cobb-Douglas Technology}

There are two countries, A and B. In both countries, production combines a fixed factor and human capital. Denoting human capital in country $i$, $i \in\{A, B\}$ by $H_{i}$, the total production is $H_{i}^{\alpha}$, where $0<\alpha<1$. As in Wildasin (1995) and Poutvaara (2000), both regions face uncertainty about the price of the exported goods. This uncertainty may take two values: prices are high when they are $1+v$ and low when they are $1-v$, where the volatility term $v$ satisfies $0 \leq v<1$. There are no taxes.

In both countries, the total population is normalized to unity. Investments in education are made before region-specific shocks are revealed. However, the educated migrate costlessly. They take into account that migration equalizes the marginal productivity of human capital in the two countries. Denoting the country which faces a positive (negative) shock by $P(N)$, we can write the migration equilibrium condition as

$$
(1-v) \alpha H_{N}^{\alpha-1}=(1+v) \alpha H_{P}^{\alpha-1} .
$$

In both countries, individuals invest in education to maximize their expected income. Investment in education is denoted by $e$. The resulting individual human capital is denoted by $h(e)$. The marginal productivity of investment in education is positive and non-increasing, so that $h^{\prime}>0$ and $h^{\prime \prime} \leq 0$. Individuals decide privately on their own investment in education, taking the market rate of return as given. This follows as there is a continuum of individuals. An individual $i$ chooses investment in education to maximize:

$$
-e_{i}+h\left(e_{i}\right)\left[\frac{1}{2}(1-v) \alpha H_{N}^{\alpha-1}+\frac{1}{2}(1-v) \alpha H_{N}^{\alpha-1}\right] .
$$

By inserting (1), this yields the first-order condition

$$
-1+h^{\prime}\left(e_{i}\right)(1-v) \alpha H_{N}^{\alpha-1}=0 .
$$

As all individuals face the identical optimization problem, they all choose an identical education in both countries. From now on, denote this by $\widehat{e}$. The condition that pre-migration and post-migration stocks of human capital are equal is 


$$
H_{N}+H_{P}=2 h(\widehat{e}) .
$$

Note that the total value of production in the two regions is $(1+v) H_{P}^{\alpha}+$ $(1-v) H_{N}^{\alpha}$. Solving $H_{N}$ and $H_{P}$ from (4) and (1), we obtain as the total value of production in the two countries

$$
Y^{W}=\left[(1+v)^{\frac{1}{1-\alpha}}+(1-v)^{\frac{1}{1-\alpha}}\right]^{1-\alpha}(2 h(\widehat{e}))^{\alpha} .
$$

Note that

$$
\begin{aligned}
& \frac{\partial}{\partial v}\left[(1+v)^{\frac{1}{1-\alpha}}+(1-v)^{\frac{1}{1-\alpha}}\right]^{1-\alpha} \\
= & {\left[(1+v)^{\frac{1}{1-\alpha}}+(1-v)^{\frac{1}{1-\alpha}}\right]^{-\alpha}\left[(1+v)^{\frac{\alpha}{1-\alpha}}-(1-v)^{\frac{\alpha}{1-\alpha}}\right]>0 . }
\end{aligned}
$$

Therefore, an increased volatility increases the total value of production in the two countries with any given investment in education. As a constant fraction $\alpha$ of this production accrues to the educated, this implies that the rate of return to any given stock of human capital increases. As investment in education equalizes the marginal cost and the return, this implies an increase in the investment in education. We can summarize the result as

Proposition 1 With a Cobb-Douglas production technology, the investment in education is increasing in the magnitude of symmetric and opposite regionspecific shocks.

Note that as $\alpha$ approaches unity, the production technology approaches the linear case. In the linear case, the marginal productivity of all human capital would equal that of the country experiencing a positive shock. Therefore, an increase in the positive shock would increase investment in human capital, in line with the findings by Katz and Rapoport (2005).

\subsection{A Quadratic Production Function}

Assume next that the production technology is quadratic. The total production in country $i$ is $a H_{i}-b H_{i}^{2}$. The region-specific shocks are the same as in the case of a Cobb-Douglas technology. Denoting again the country 
which faces a positive (negative) shock by $P(N)$, we can write the migration equilibrium condition as

$$
(1-v)\left(a-2 b H_{N}\right)=(1+v)\left(a-2 b H_{P}\right) .
$$

An individual $i$ chooses investment in education to maximize:

$$
-e_{i}+h\left(e_{i}\right)\left[\frac{1}{2}(1-v)\left(a-2 b H_{N}\right)+\frac{1}{2}(1+v)\left(a-2 b H_{P}\right)\right] .
$$

By inserting (5), this yields the first-order condition

$$
-1+h^{\prime}\left(e_{i}\right)(1-v)\left(a-2 b H_{N}\right)=0 .
$$

As the maximization problem is the same in both ex ante identical countries, the solutions are identical. Solving $H_{P}$ from (4) and inserting it into (5) yields

$$
H_{N}=h(\widehat{e})-\frac{v}{2 b}(a-2 b h(\widehat{e})) .
$$

The rate of return to human capital is then

$$
(1-v)\left(a-2 b H_{N}\right)=\left(1-v^{2}\right)(a-2 b h(\widehat{e})) .
$$

Note that this is both the expected and the realized rate of return: as the two countries face opposite shocks, there is no uncertainty about the post-migration productivity of human capital. Differentiation yields

$$
\frac{\partial}{\partial v}\left[\left(1-v^{2}\right)(a-2 b h(\widehat{e}))\right]=-2 v(a-2 b h(\widehat{e})) .
$$

Note that $a-2 b h\left(e_{i}\right)$ has to be positive, as otherwise the marginal productivity of human capital would be negative. The right-hand side of (6) is thus negative. This implies that with any given investment in education, an increase in the region-specific shocks reduces the expected rate of return to human capital investment. Thus, it would reduce investment in human capital. We can summarize the result as

Proposition 2 With a quadratic production technology, the investment in education is decreasing in the magnitude of symmetric and opposite regionspecific shocks. 
Contrary to the finding with linear and Cobb-Douglas production technologies, region-specific shocks would reduce investment in human capital with a quadratic production technology.

\section{Conclusion}

Previous literature has concluded that the possibility of migration boosts human capital formation with region-specific shocks (see Poutvaara (2000) and Katz and Rapoport (2005) for analysis of countries with same expected returns to education, and references therein on contributions where the expected rates of return differ). This paper shows that this result is sensitive to the assumptions about the production technology. The results that Poutvaara (2000) derives with a Cobb-Douglas technology and Katz and Rapoport (2005) with a linear production technology may be reversed with quadratic production technology.

\section{References}

[1] Katz, E, Rapoport, H (2005) On Human Capital Formation with Exit Options. Journal of Population Economics 18(4):267-274

[2] Köthenbürger, M, Poutvaara, P (forthcoming) Social Security Reform and Investment in Education: Is there Scope for a Pareto-Improvement? Forthcoming in Economica

[3] Poutvaara, P (2000) Education, Mobility of Labour, and Tax Competition. International Tax and Public Finance 7(6):699-719

[4] Wildasin, DE (1995) Factor Mobility, Risk and Redistribution in the Welfare State. Scandinavian Journal of Economics 97(4):527-546 